\title{
Grammatical Errors in the English Translation Made by the Students of English Study Program of UKI Toraja
}

\author{
Matius Tandikombong \\ matthewtandi@yahoo.com \\ Haryanto Atmowardoyo \\ aharyanto_fbsunm@yahoo.co.id \\ Sukardi Weda \\ sukardiweda@yahoo.com \\ State University of Makassar, Indonesia
}

\begin{abstract}
This research is aimed at describing the grammatical errors made by the students in translating Indonesian into English. Four objectives are fromulated: 1.To find out the types of errors that the students make in translating sentences from Indonesian into English 2.To find out the most frequent errors made by the students of UKI Toraja 3.To find out the source of error that the students make in translating Indonesian text into English text and 4. To find out the differences in number of grammatical errors made the students of different levels of UKI Toraja. The method used was a descriptive method. The population of this research was the fourth-semester and the sixth-semester students of UKI Toraja in the academic year 2014/2015. The fourth-semester students consisted of 270 as the population in this research. Thirty (30) students were taken as the sample. The sixth-semester students also consisted of 270 students as a population in this research and30 students were taken as the sample. The research findings reveal that the most frequent errors in both levels are errors in verbs; and that most of the errors are due to overgeneralization and the ignorance of the rule restriction.
\end{abstract}

Keywords: Grammatical errors, Indonesian text, English text, Verb, Noun, Conjunction, Pronoun, Adjective, Adverb, Article, Preposition.

\section{Introduction}

Translation is one of the important skills in studying a language. Translation is the one of the ways to acquire language as a second or foreign language so that Translation skill is much needed in learning English as a second or foreign language. Newmark in Suryawinata (2003:15) states that translation is a craft in the attempt to replace a 
$2 \mid$ ELT Worldwide Vol. 3 No. 1 April 2015

written message and or statement in one language by the same message and/or statement in another language. Translation, as a process, is always uni-directional, meaning that it is always performed in a given direction ' from' a source language (henceforth abbreviated) into a target language (Rachmadie et. al., 1999:2).

To produce a good translation, the translator has to know almost perfectly the language translate from, and above all, the language to be translated into. There has to be no mystery for the translator in the original text, has to understand every nuance. Otherwise, he will lose pieces of information. In other words, translation is not merely the transfer of words in L1 into those L2 or vice versa.

One of the language aspects required in translating English text is grammar. Howard Jackson (2005: 131) argues that grammar is the means by which we structure the language that we speak and write as a consequence of acquiring or learning the language; or a set of rules, conventions, and principles, together with their exceptions, that we have stored in our heads ('internalized') The other aspect is wordchoice, the one that decides whether or not a product of translation makes sense.

This study aims to identify grammatical errors made by the students of English Study Program Faculty of Teacher Training and Education of UKI Toraja in translating source language into a target language namely translating Indonesian text into English text. The major types of errors made by the students in translation are related to incomplete sentence: the use of verbs, nouns, adjectives, adverbs, pronouns, articles, prepositions and conjunction agreement in the sentences In both oral and written communication, for example, grammar might be a problem for the students to face as they need to arrange the information when they translate the source language into a good sentence structure in the target language.

The results of this research will provide EFL learners with some helpful guidance in order to minimize the number of errors in second or foreign language production. 
Tandikombong, Atmowardoyo, Weda : Grammatical Errors ... $\mid 3$

\section{Literature Review}

1. The concept of errors

Dulay et.al. in Josefa (2003: 67) defined errors as "the flawed side of learner speech or writing", which "deviates from some selected norm of mature language performance". They further discussed that errors may be distinguished based on the causes: errors caused by factors such as fatigue and inattention are "performance errors", and those caused by lack of knowledge of the rules of the language are called "competence errors. Brown in Josefa (2003:68) also made a distinction between mistakes and errors based on the sources.

A mistake indicates "a failure to utilize a known system correctly" whereas an error "reflects the competence of the learner" (20003: 68). It was also admitted, however, that one may not be able to "tell the difference between an error and a mistake" in all occasions (2003 : 68). It was emphasized that the important thing is that learners "do make errors, which can be observed, analyzed and classified to reveal something of the system operating within the learners".

\section{The concept of error analysis}

Ellis in Said ( 2014: 28) stated that error analysis involves a set of procedures for identifying, describing and explaining the error in learner language. Error Analysis, a branch of Applied Linguistics emerged in the sixties to reveal that learner errors were not only because of the learner's native language but also they reflected some universal strategies. Error analysis is a reaction to Contrastive Analysis Theory which considered native language interference as the major source of errors in the second language learning what behavioristic theory suggested ( Ali Akbar Khansir 2012).

Corder in Kao, Chyi-Ching (1998:5) says that error analysis has practical uses and applications for language teachers: Errors Enable the teacher to decide whether he can move on to the next item on the syllabus or whether he must devote more time to the item he has been working on. This is the day-to-day value of errors. But in terms of broader planning and with a new group of learners they provide the information of teaching. 
According to Sunardi (2002), error analysis is an activity to reveal errors found in writing and speaking. Richards et.al in Sunardi (2002:

43) state that error analysis is the study of errors made by the second and foreign language learners.

Error analysis is as a source of information for the teacher. By the information it can help the teacher, classify and interpreted or describe the errors made by the students in speaking or in writing and to correct students' error and also to improve the effectiveness of their teaching.

The writer decided to conduct an error analysis as the best way for describing and explain error made by the students in translating of another language in order to know the source of these errors.

3. The concept of translation

According to Nida in Rachmadie (1999:1) translation consists in reproducing in the receptor language the closest natural equivalent of the source-language message, first in the term of meaning and secondly in the terms of style.

Darwish (2003) maintains that the conveyance of the message consists essentially of converting the verbal expression of the message in one language into a corresponding verbal expression in the other language Translation is not a monistic composition, but an interpenetration and conglomerate of two structures. On the one hand, there are the semantic content and the formal contour of the original, on the other hand, the entire system of aesthetic entire system bound up with the language of the translation. In translation, there is a substitution of TL meanings for SL meanings: not transference of TL meanings into the SL In transference there is an implantation of SL meanings into the TL text. These two processes must be clearly differentiated in any theory of translation ( Bassnett $2005: 16$ )

Translation process in a foreign language or second language acquisition is not only the process of conveying meaning from the source language (SL) to the target language (TL), the benefit of translation go further. It is a pedagogic method that facilitates learning of four language skills and makes a foreign language more comprehended to English language learners, especially in their first levels of learning, particularly those who struggle to express 
Tandikombong, Atmowardoyo, Weda : Grammatical Errors ... $\mid 5$

themselves by using a totally new system of verbal or written communication.

\section{The concept of grammar}

According to Thornbury (1999), grammar is partly the study of what forms (or structure) are possible in a language. Traditionally, grammar has been concerned almost exclusively with analysis of the level of the sentences. Thus, grammar is the description of the rules that govern how a language's sentences are formed. Grammar is a term used to mean many different things. When teachers and administrators grow frustrated over error in students' writing, They often call for a return to " the basic" which they define as grammar (Williams in Adu. 2012.:25)

According to Valeika and Bulkier (2003.:23), "The term grammar is derived from the Greek word grammatikē, where gram meant something written. The part tikē derives from technē and meant art. Hence, grammatike is the art of writing. Since its appearance in ancient Greece, the term has undergone considerable modifications. In ancient Greece and ancient Rome, the terms grammatike and grammatical respectively denoted the whole apparatus of literary study. Grammatical mean two things: 1). Generated by the application of phrase structure and transformation rule, 2). Generated by the application of the lexical or semantic rule. For example "Green ideas sleep furiously" is not grammatical because it violates the rule of semantic compatibility. Greenbaum, Nelson (2002) state that grammar refers to the set of rules that allow us to combine words in our language into larger units.

\section{Research Method}

This study may be classified as a descriptive research, a kind of study designed to describe the existing phenomena. Several common steps of error analysis adopted from Atmowardoyo (2010: 56) were taken. First, identifying errors, that is identifying any grammatical errors through the process of coding; second, classifying errors into error types which might be grouped in accordance with the grammatical area (e.g. errors in articles, errors in nouns, errors in verbs, etc) and; and third, formulating a statement of error frequency. The population of this research were the fourth and the sixth-semester students of 
6| ELT Worldwide Vol. 3 No. 1 April 2015

English study program of UKI Toraja in academic year 2014/2015. Where the fourth-semester consists of nine classes and each class consists of 30 students so the population in this semester consists of 270 students and the sixth-semester consists of nine classes and each class also consists of 30 students so the populations in this semester are 270 students. There were 60 students. There were 30 students taken from the fourth semester and 30 students was taken from the sixth semester. They were selected by using cluster random technique.

To obtain the data, the researchers administered a translation test as the instrument of the research. In this written test the students were given an Indonesian text and then they translated the text into English text. Data collected in this research were the students' answer sheet. Those answer sheets were collected to facilitate the researchers in identifying grammatical errors made by the students in translating Indonesian text into English text. The data collected from written test was analyzed by using error analysis technique. The error analysis of this research comprised of five steps, that is, eliciting the students' translation works, identifying the errors, classifying of the errors into types of errors, grouping the errors in terms of grammatical areas, and explaining the causing factors of the errors.

\section{Findings}

\section{a. Grammatical errors}

The table 1 shows that the total of error made by the students in translating Indonesian text into English text. There were 715 errors made by the fourth-semester students in translation in a wide variety of type of errors. There were $280(39.16 \%)$ errors in verb, $237(33.15 \%)$ errors, $22(3.07 \%)$ errors in conjunction, $15(2.09 \%)$ errors in pronoun, $118(16.5 \%)$ errors in adjective, $14(1.96 \%)$ errors in adverb, 9(1.26\%) errors in article errors and 20 (2.79\%) errors in preposition. While the sixth-semester students' errors in translation were 578 in a wide variety of type of errors, there were $256(44.29 \%$ ) errors in verb $173(29.9 \%)$ errors in noun .There were $20(3.46 \%)$ errors in conjunction, $12(2.07 \%)$ errors in pronoun, $80(13.84 \%)$ errors in adjective, $11(1.93 \%)$ errors in adverb $8(1.38 \%)$ errors in article and $18(3.12 \%)$ errors in preposition. 
Tandikombong, Atmowardoyo, Weda : Grammatical Errors ... $\mid 7$

Table 1. Total of the students' errors

\begin{tabular}{llllll}
\hline No & $\begin{array}{l}\text { Types of } \\
\text { error }\end{array}$ & $\begin{array}{l}\text { Fourth } \\
\text { semester }\end{array}$ & \multicolumn{3}{l}{$\begin{array}{l}\text { Sixth } \\
\text { Semester }\end{array}$} \\
\hline 1 & Verb & 280 & $39.16 \%$ & 256 & $44.29 \%$ \\
2 & Noun & 237 & $33.15 \%$ & 173 & $29.93 \%$ \\
3 & Conjunction & 22 & $3.07 \%$ & 20 & $3.46 \%$ \\
4 & Pronoun & 15 & $2.09 \%$ & 12 & $2.07 \%$ \\
5 & Adjective & 118 & $16.56 \%$ & 80 & $13.84 \%$ \\
6 & Adverb & 14 & $1.96 \%$ & 11 & $1.9 \%$ \\
7 & Article & 9 & $1.26 \%$ & 8 & $1.38 \%$ \\
8 & preposition & 20 & $2.79 \%$ & 18 & $3.12 \%$ \\
\hline & sum & 715 & & 578 & \\
\hline
\end{tabular}

Table 1 shows the most frequent errors made by the students in translating Indonesian text into English text. The most frequent errors made by the fourth semester students in translating were verb errors with $39.16 \%$ followed by noun errors with $33.15 \%$ and adjective errors $16.56 \%$, conjunction errors $3.07 \%$ preposition errors $2.79 \%$, pronoun errors $(2.09 \%)$, adverb errors $1.96 \%$, and the last one was article errors $1.26 \%$. while The most frequent error made by the sixth semester students in translation were verb errors with $44.29 \%$ followed by noun errors with $29.93 \%$, and adjective $13.84 \%$, conjunction errors $(3.46 \%)$, preposition errors $3.12 \%$, pronoun errors $2.07 \%$, ) adverb errors $1.9 \%$ ) and the last one was article errors with $(1.38 \%)$.

\section{b. Source of errors}

From the perspective of error causes, there were overgeneralization, ignorance of rule restriction, incomplete application of rule and false concept hypothesis.

Table 2. The Causes of Errors in Percents

\begin{tabular}{llllll}
\hline No & Causes & $\begin{array}{l}\text { Fourth } \\
\text { semester }\end{array}$ & $\%$ & $\begin{array}{l}\text { Sixth } \\
\text { semester }\end{array}$ & $\%$ \\
\hline 1 & Overgeneralization & 216 & $37.82 \%$ & 196 & $42.79 \%$ \\
2 & Ignorance of rule restriction & 163 & $28.89 \%$ & 117 & $25.54 \%$ \\
3 & Incomplete application rule & 47 & $8.23 \%$ & 42 & $9.17 \%$ \\
4 & False concept hypothesis & 143 & $25.04 \%$ & 103 & $22.48 \%$ \\
\hline & Sum & 571 & $100 \%$ & 458 & $100 \%$ \\
\hline
\end{tabular}


Table 2 shows the most dominant causing factors of the both group' errors was an overgeneralization. The total causing errors factors in the fourth-semester students was 216. The distribution of the causing factors in the group were $216(37.82 \%)$ overgeneralization, 163 (28.87\%) ignorance of rule restriction, 143(25.04\%) false concept hypothesis and 47(8.23) incomplete application rule. While the total causing errors factors in the sixth-semester students were 458. There were 196 (42.79\%) overgeneralization, 117(25.54\%) ignorance of rule restriction, $103(22.48 \%)$ false concept hypothesis and $42(9.17 \%)$ incomplete application rule.

The differences between the both groups were overgeneralization and ignorance the of rule restriction. But above all the most causing factors of both groups were overgeneralization and ignorance of rule restriction.

\section{Discussion}

1. The types of errors made by the fourth-semester students' translation

Based on the result of analysis, the types of error made by the students in translating are varied. The type of errors error in verb, noun, conjunction, pronoun, adjective, adverb, article, and preposition and The most frequent errors made by the fourth semester for this division are errors in verbs. Table 1 shows the most frequent errors made by the students in translating Indonesian text into English text. the most frequently errors made bay the fourth semester students in translating were verb errors with $(39.16 \%)$, followed by noun errors $(33.15 \%)$, and then adjective errors (16.56\%), conjunction errors $(3.07 \%)$ preposition errors $(2.79 \%)$, pronoun errors $(2.09 \%)$, adverb errors $(1.96 \%)$, and article errors $(1.26 \%)$.

2. The causing factor of errors made by the fourth-semester students' translation

In relation to the causing factors of errors, the finding shows that the students' errors in translating Indonesian text into English text are caused by some major factors. Where these factors have been known and investigated by many researchers. In this research, the causing 
Tandikombong, Atmowardoyo, Weda : Grammatical Errors ... $\mid 9$

factors are divided into four divisions covering overgeneralization, ignorance of the rule restriction, incomplete application of rules, and false concept hypothesized. The most frequent error made by the fourth semester is overgeneralization becomes dominant causing factors with $280(39.16 \%)$ then followed by ignorance of rule restriction with $163(28.89 \%)$ and then false concept hypothesis $143(25.04 \%)$ while the last dominant causing factor is incomplete application of rule $47(8.23 \%)$.

\section{Types of errors made by the sixth-semester students' translation}

Based on the result of analysis, the types of error made by the students in translating are varied. The type of errors error in verb, noun, conjunction, pronoun, adjective, adverb, article, and preposition and The most frequent error made by the sixth semester for this division are errors in verbs. Table 1 shows the most frequent errors made by the sixth students in translating Indonesian text into English text. the most frequently made bay the sixth semester students in translating were verb errors with $(44.29 \%)$ followed by noun errors with (29.93\%), and then adjective (13.84\%), and then conjunction errors $(3.46 \%)$, preposition errors $(3.12 \%)$,pronoun errors $(2.07 \%$, adverb errors $(1.9 \%)$ and article errors (1.38\%).

4. The causing factor of errors made by the sixth-semester students

In relation to the causing factors of errors, the finding shows that the students' errors in translating Indonesian text into English text are caused by some major factors. Where these factors have been known and investigated by many researchers. In this research, the causing factors are divided into four divisions, they are the overgeneralization, ignorance of the rule restriction, incomplete application of rules, and false concept hypothesized. The most frequent error made by the sixth-semester students was overgeneralization becomes dominant causing factors with $196(42.79 \%$ then followed by ignorance of rule restriction 117(25.54\%), false concept hypothesis 103(22.48\%) and the last dominant causing factor is the incomplete application of rule $42(9.17 \%)$. 
10| ELT Worldwide Vol. 3 No. 1 April 2015

5. The error comparison between the fourth-semester students and the sixth-semester students.

Based on the finding the fourth and the sixth-semester students have little difference in making errors when they translated the Indonesian text into English text. The fourth-semester students made 715 (55.29) errors while the sixth-semester students made 578 (47.9) errors. The difference was 138 (10.59) It indicates that the sixth-semester students' progress in the grammatical was significance.

The frequent errors made by the second and the sixth-semester students were different in number. However, the fourth-semester students and the sixth-semester students made the most frequent errors in the same area. Both groups made errors in verb area. the fourthsemester students made $280(39.16 \%)$ errors while the sixth-semester students made 256(44.29\%) errors. And the next frequent errors was noun, the fourth semester students made 237(33.15) errors in this area and the sixth semester students made 173(29.93)errors and the third frequent errors made the fourth semester students was adjective with 118(16.56)errors while the sixth semester students made 80(3.46)errors and the fourth frequent errors made by the fourth semester students was preposition with 22(3.07)errors and the sixth semester students made 20(3.46) errors. The fifth frequent errors made by the fourth-semester students were preposition with 20(2.79) errors while the sixth-semester students made 18(3.12) errors. The sixth frequent errors made by the students were pronoun with 15(2.09) errors while the sixth-semester students made 12(2.07) errors. And the next frequent errors made by the fourth-semester students was Adverb with 14(1.96) errors and the sixth-semester students made 11(1.9) errors. And the last frequent errors made by the fourth-semester students was Article with 9(1.26) errors and it was only done by 8 students while the sixth-semester students made $8(1.38 \%)$ errors and it was done by 8 students.

In terms of to the causing factors, the fourth-semester students made more overgeneralization $216(37.82 \%)$ while the sixth-semester students 196(42.79\%). According to Richards (1974:174), overgeneralization generally involves the creation of one deviant structure in place of two regular structures. 
Tandikombong, Atmowardoyo, Weda : Grammatical Errors ... $\mid 11$

Generally, the most causing factors of the students' error were overgeneralization errors. Which contributed $412(40.03 \%)$ to the total number of causing factors. There was not the major difference between the fourth and the sixth-semester students. The first causing factor of both groups was the overgeneralization, followed by ignorance of rule restriction and then false concept hypothesis and the last factor is incomplete application rule.

6. The frequent error made by the fourth and the sixth-semester students

There are ten similar studies that have revealed the grammatical errors in English that can be displayed as follows:

The comparison of the finding of the present study to those of others

\begin{tabular}{|c|c|c|c|}
\hline NAME OF STUDY & DATA & SUBJECTS & FINDINGS \\
\hline Usaha (2013) & Witting errors & Learners & $\mathrm{V}>$ pre>others \\
\hline Suwangard (2014) & narration & Learners & V>others \\
\hline Hasyim (2002) & $\begin{array}{l}\text { Writing } \\
\text { Teaching English }\end{array}$ & $\begin{array}{l}\text { Learners } \\
\text { and teachers }\end{array}$ & V> Others \\
\hline Mardojono (2013) & writing & learners & V>others \\
\hline Salvador (2008) & Narrative writing & learners & $\mathrm{V}>\mathrm{Ar}>\mathrm{Con}>$ Pro $>$ Others \\
\hline Handriwanto (2013) & Essay written & Learners & V $>$ Con $>$ Pro $>$ others \\
\hline Tae (2013) & $\begin{array}{l}\text { Writing } \\
\text { Competence }\end{array}$ & Learners & $V>N>A r>$ Pre Pro $>A j>A d$ \\
\hline Hui-mien (2007) & English Writing & Learners & V > Pre > others \\
\hline Atmowardoyo (2007) & Essay writing & $\begin{array}{l}\text { Indonesian } \\
\text { EFL } \\
\text { Learners }\end{array}$ & Verb Patterns>others \\
\hline Ching (2012) & Translation & Learner & V>others \\
\hline Nonkukhetkhong(2013) & & Learner and & $\mathrm{V}>\mathrm{N}>\mathrm{Ar}>$ Pre $>$ Pro $>\mathrm{Ad}>\mathrm{Av}$ \\
\hline The present Study & & Teacher & $\mathrm{V}>\mathrm{N}>\mathrm{Aj}>\mathrm{C}>\mathrm{Pre}>\mathrm{Pro}>\mathrm{Av}>\mathrm{Ar}$ \\
\hline \multicolumn{2}{|c|}{$\mathrm{V}=\mathrm{Verb}$} & & $\mathrm{Aj}=$ Adjective \\
\hline \multicolumn{2}{|c|}{$\mathrm{N}=$ noun } & & $A v=A d v e r b$ \\
\hline \multicolumn{2}{|c|}{$\mathrm{C}=$ conjunction } & & Ar $=$ Article \\
\hline \multicolumn{2}{|c|}{ Pro=Pronoun } & & Per=Preposition \\
\hline
\end{tabular}

The most frequent errors made by the two groups in the present study were verb error followed by noun error, adjective error, conjunction error and pronoun. The findings are similar to some of the previous studies conducted in some different countries. Atmowardoyo (2007) reported a finding that Indonesian EFL learners made most errors in verb patterns. 
Usaha (2013), for example, conducted the research analyzing writing errors caused by the interference of the Thai language in writing narration Found five most frequent errors made by the Thai students there were: verb tense word choice, sentence structure, preposition and modal/auxiliary, respectively. Salvador (2008) conducted about Analysis of Errors in the Essays Written by Math, Science and Engineering Faculty report the same finding. The second is Suwanggard (2014) ) who conducted a research under the title " Grammatical Error Correction and Retention in EFL Students: A Case Study of EFL Students in Thailand" This study aimed to examine grammatical error types, retention of the correction in the students' writing, and their opinions on the error correction he found that the most error made by the Thailand students was verb. Salvador (2008) conducted about Errors in the Essays Written by Math, Science and Engineering Faculty, and he reported the same finding. The same finding is also reported by Handriwanto (2013) who conducted an analysis of the grammatical errors in the narrative writing of the firstgrade students of SMA 6 Yogyakarta. The fifth is Tae (2013), who conducted an error analysis in English writing made by Chinese and Korean University Students and found the same finding. Hui-Mien (2007) also conducted a study of EFL learners' writing errors and instructional strategies. The last study, Ching (2009) also found the same finding. All indicate that learners make errors in verbs more than in the other areas.

The major causes of these errors were attributable to limited vocabulary size poor grammar knowledge and interference from the first language. In this case the students of UKI Toraja had the same similar error in common such noun error, verb error adjective error, conjunction error and pronoun error when they translate Indonesian text into English text.

In Nonkukhetkhong study, the highest error of the First Year English Major Students in learning ESL and EFL in Thailand was "verb" with $88(14.69 \%)$ which was caused by omission, misinformation, misordering, and overgeneralization. The students of UKI Toraja also did the same errors, where the most errors made by students of UKI Toraja was verb errors with 536 (41.45) errors which were caused by overgeneralization had dominant factors in this type of errors besides ignorance of rule restriction. 
Tandikombong, Atmowardoyo, Weda : Grammatical Errors ... $\mid 13$

\section{Conclusion}

The types of error made the students in translating Indonesian text into English are dealing with the grammatical area are classified as follows:

Errors in the verb area are in the forms of missing verbs, errors of verb tense, incorrect negative form, to infinitive and participle errors. In the noun area, the errors consist of the missing nouns, singular/plural misplace, and inappropriate choice. Errors in the conjunction area consist of missing conjunction, superfluous, inappropriate choice errors. In area pronoun consist of missing pronoun, Superfluous, misplace. Errors in the adjective area consist of: missing adjective, Superfluous, misplace, inappropriate choice and errors in the adverb area involve missing adverb, Superfluous, misplace, inappropriate choice. Errors in the article area consist of missing article, superfluous, inappropriate choice and the last one is errors in the preposition areas consist of; missing preposition, superfluous, inappropriate choice. The most frequent error made by the students in translating Indonesian text into English text is errors in verbs. In this area, the students make 536 errors. It means that the students make $41.45 \%$ errors from the total errors. Relating to the causes of errors, it was influenced by overgeneralization and ignorance of rule restriction.

\section{Suggestion}

Considering the conclusions above researcher would like to offer some suggestion as follows:

1. The English lecturer should give clearer explanations about grammatical rules in English, particularly in the verb area, because based on the result of this research errors in verb area is the most frequent errors made by the students in translation because all of the students made errors in this area.

2. The lecturers are also expected to teach more effectively and should give more exercises in applying grammar not only giving 
14| ELT Worldwide Vol. 3 No. 1 April 2015

the theory of grammar. In this case, the students should be encouraged in using correct grammar in English.

3. After knowing the students' difficulties in using correct grammar, the teacher is expected to be able to solve the students' difficulty by providing appropriate teaching materials.

4. It is necessary to the lectures to give a remedial teaching on the grammatical feature to minimize the students in producing errors in translation.

\section{REFERENCES}

Atmowardoyo, Haryanto. 2007. Grammatical Errors Made by Indonesian EFL Learners. A Paper presented on the Konferensi Linguistik Tahunan Atmajaya (KOLITA), Universitas Katolik Atmajaya, Jakarta.

Atmorwardoyo, Haryanto. 2010. Research methods for language and literature studies. Makassar: Badan Penerbit Universitas Negeri Makassar.

Bassett, Susan. 2002. Translation Studies.Third edition. Taylor \& Francis e-Library, London and New York.

Ching, Hei Khor. (2009). Common Errors in Written English Essay of Form one Chinese Student. University Kebangsaan Malaysia.

Ellis, Rod.,1997. Second language acquisition. Oxford university press.

Gay,L.R., Geoffery E. Mils, and Peter Airasian. 2006. Education Research: Competencies for analysis and Application. New Jersey: Pearson Prentice Hall

Jackson, Howard. 2005. Good Grammar for students. Sage Publication London. Thousand Oaks. Delhi.

Kao, Chyi-Ching., 1998. An Investigation into Lexical, Grammatical, and Semantic Errors in English Compositions of College Students in Taiwan. Soochow University and Fu Hsing Kang College. 
Tandikombong, Atmowardoyo, Weda : Grammatical Errors ... $\mid 15$

Mardijono, Josefa J. 2003. Indonesian EFL Advanced Learners' Grammatical Errors. Volume 5 number 1.

Newmark, Peter. 1988. A textbook of translation. Prentice. New York London Toronto Sydney Tokyo.

Nida, Eugene H., 1963. Toward a science of translating. New York.

Rachmadie, Sabrony, Zuchridin Suryawinata dan Achmad Effendi (1999) Translation. Universitas Terbuka

Richards, Jack C. 1974. error analysis perspective on second language acquisition. Longman.

Said, Dian Riany., 2014. Error analysis in descriptive writing made by the sixth-semester students at STKIP Muhammadiyah Bone. Unpublished Master Thesis. Makassar: State University of Makassar.

Suryawinata, Zuchridin \& Sugeng Hariyanrto, 2003. Translation (bahasan teori \& penentuan practis menerjemakan.Kanisius.

Suwangard, Niramon., 2014. Grammatical Error Correction and Retention in EFL Students in Thailand, IOSR Journal of Humanities and Social Science (IOSR-JHSS) Volume 19, Issue 12, Ver. IV (Dec. 2014), pp. 51-58 